\title{
ICE review
}

A review of recent developments at the Institution of Civil Engineers by ICE president John Armitt. For further information please contact the communications office on +44 207665 2107, email communications@ice.org.uk or visit www.ice.org.uk//news-public-affairs.

\section{UK infrastructure body 'official'}

In May, while setting out the UK government's legislative programme for the coming year, the Queen confirmed that the National Infrastructure Commission chaired by Andrew Adonis - and of which I am a member - will be formalised in statute.

Setting the commission on a statutory and independent footing will confirm and uphold its role and purpose. This is an important milestone for UK civil engineering. Certainly the mood in the commission is now very positive as we work towards developing proposals for rolling out the next generation $(5 \mathrm{G}$ ) of mobile telecommunications networks.

We are also looking at providing infrastructure proposals for the Cambridge-Milton Keynes-Oxford corridor that will unlock growth, jobs and housing. The area contains some of the UK's fastest growing and most productive places, with global centres of research in Oxford and Cambridge and advanced manufacturing and logistics in Milton Keynes. Our review will recommend how to maximise the potential of the area as a single, knowledge-intensive cluster that competes on a global stage.

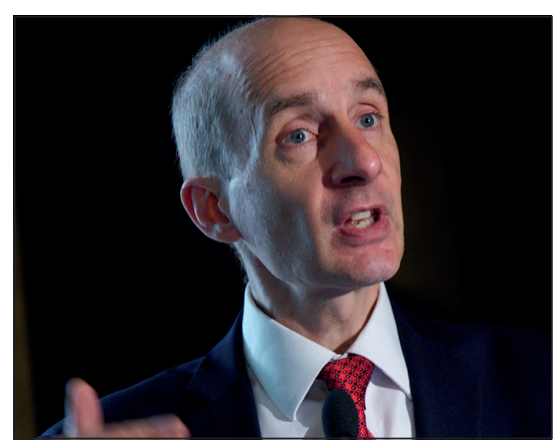

Andrew Adonis, chair of the National Infrastructure Commission which is now to become statutory independent body

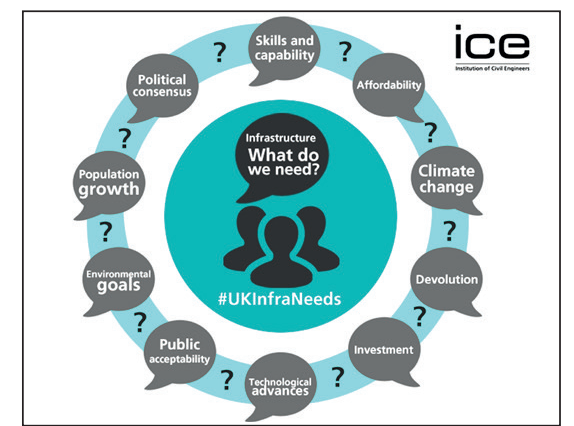

ICE's evidence gathering covered all aspects of UK infrastructure needs - the findings will be published in autumn 2016

\section{Proving UK infrastructure needs}

Evidence gathering for ICE's

independent assessment of Britain's infrastructure needs is now complete. The findings will be published in autumn this year and presented to the National Infrastructure Commission.

The response to ICE's nationwide call for written evidence and a series of engagement events and workshops has been huge, providing us with a wealth of evidence and expertise. Over 400 organisations and individuals from across the infrastructure sector contributed.

The collaborative nature of the project has played a part, creating a real sense of excitement, and it has been a pleasure for me to chair the executive group. We have a collection of very different organisations - including Pinsent Masons, KPMG and the University of Oxford working together ultimately to benefit society, grow the economy and drive the shift to a low carbon dioxide future.

Research by the Oxford Universityled Infrastructure Transitions Research Consortium will also form part of the evidence base, along with other economic and environmental data. Our aim is to establish an independent evidence base on the UK's infrastructure needs up to 2050 and facilitate more strategic choices.

\section{Studying nature's engineers}

A fascinating paper on termite engineering in the April 2016 issue of ICE's Environmental Geotechnics journal has been widely covered in the media. Written by the Indian Institute of Science in Bangalore, it looked at the effectiveness of construction techniques used by the mound-building termite and their potential application in civil engineering.

The paper revealed that the welldocumented 'bio-cementation' process used by termites - where grains of soil are bonded into balls and then stuck together - actually makes their mounds ten times stronger than structures built from unmodified materials.

The paper was widely covered in engineering and construction trade publications, many of which described the termite as one of nature's top engineers. Stories like these - where engineers learn and benefit from nature - are important in engaging the media and public on engineering. They also show the breadth of depth of ICE's international journal publishing programme - see www.icevirtuallibrary.com for more information.

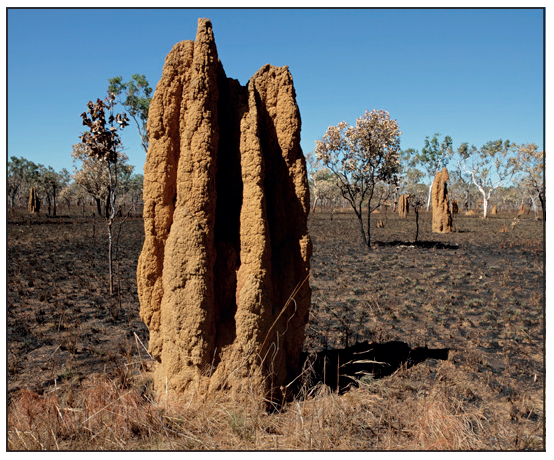

An ICE journal paper revealed that biocementation processes used by termites makes their structures ten times stronger 